\title{
Improved Stabilities of Immobilized Glucoamylase on Functionalized Mesoporous Silica Synthesized using Decane as Swelling Agent
}

\author{
Reni George, Sanjay Gopinath, Sankaran Sugunan * \\ Department of Applied Chemistry, Cochin University of Science and Technology, \\ Kochi-682022, Kerala, India.
}

Received: 3rd December 2012; Revised: 4th April 2013; Accepted: 20th April 2013

\begin{abstract}
Ordered mesoporous silica, with high porosity was used to immobilize glucoamylase via adsorption and covalent binding. Immobilization of glucoamylase within mesoporous silica was successfully achieved, resulting in catalytically high efficiency during starch hydrolysis. In this study, mesoporous silica was functionalized by co-condensation of tetraethoxysilane (TEOS) with organosilane (3-aminopropyl) triethoxysilane (APTES) in a wide range of molar ratios of APTES: TEOS in the presence of triblock copolymer P123 under acidic hydrothermal conditions. The prepared materials were characterized by Small angle XRD, Nitrogen adsorption - desorption and ${ }^{29}$ Si MAS solid state NMR. $\mathrm{N}_{2}$ desorption studies showed that pore size distribution decreases due to pore blockage after functionalization and enzyme immobilization. Small angle XRD and ${ }^{29} \mathrm{Si}$ MAS NMR study reveals mesophase formation and Si environment of the materials. The main aim of our work was to study the catalytical activity, effect of $\mathrm{pH}$, temperature, storage stability and reusability of covalently bound glucoamylase on mesoporous silica support. The result shows that the stability of enzyme can be enhanced by immobilization. (c) 2013 BCREC UNDIP. All rights reserved
\end{abstract}

Keywords: Mesoporous silica; Glucoamylase; Immobilization; Hydrothermal; Covalent bond.

How to Cite: George, R., Gopinath, S., Sugunan, S. (2013). Improved Stabilities of Immobilized Glucoamylase on Functionalized Mesoporous Silica Synthesized using Decane as Swelling Agent. Bulletin of Chemical Reaction Engineering \& Catalysis, 8 (1): 70-76. (doi:10.9767/bcrec.8.1.4208.70-76)

Permalink/DOI: http://dx.doi.org/10.9767/bcrec.8.1.4208.70-76

\section{Introduction}

Glucoamylase (EC 3.2.1.3) is an exoacting enzyme that yields B-D-glucose from the non reducing chain ends of amylase, amylopectin and glycogen by hydrolyzing $\alpha-1,4$ linkages in a consecutive manner [1-2]. It is an industrially important enzyme used in large scale for liquefaction and saccharifi-

* Corresponding Author.

E-mail: renigeorge@cusat.ac.in (R. George) ssg@cusat.ac.in (S. Sugunan)

Tel: + 91-484-2575804. Fax: +91-484-2577595 cation of starch in the food and beverages industry [3]. Bio-immobilization increases operational stability, easy recovery of products at the end of reaction and storage stability of the enzyme. Glucoamylase effectively immobilized on different supports like porous glass, chitin, polymers [4-6], carboxyl functionalized magnetic nano particles [7-8], bacterial cellulose bead [9], glyoxal agrose [10] and on carbon support sibunit, bulk catalytic filamentous carbon (bulk CFC), activated carbon(AC) [11] and calcined chicken bone particles [12]. Support with appropriate pore diameter is very essential to incorporate the enzyme there should be a perfect match in size between the enzyme and pore struc- 
ture of the support because enzyme has its own specific size [13]. The molecular size of glucoamylase is $80 \AA$, that the prepared silica materials were tuned in such a way to accommodate the enzyme molecules inside the channels. Due to tunable pore size, high adsorption capacity, thermal and mechanical stability which makes mesoporous silica as a versatile immobilization support. Porous silica materials were regarded as suitable immobilizing hosts for large molecules like proteins because of their structural characteristics such as large surface area, high pore volume, well ordered structure and abundant silanol groups [14-15]. The mesoporous materials yield a type IV adsorption isotherm with a type-H1 hysteresis and also possess $2 \mathrm{D}$ hexagonal p6mm symmetry [16-21]. The properties of silica material is independent of silica source and nature of the amphiphilic co-polymer but depends solely on the amount of co-solvent used, it indicates that co-solvent function as a swelling agent. Namba et al. explained the addition of an auxiliary chemical to the synthesis medium which increases the pore size drastically [22]. Alkanes, benzene, methyl substituted benzene etc. can be used as swelling agents to enlarge the pore diameter [23].

Enzymes were immobilized through physical adsorption, covalent binding, matrix entrapment etc. But the major disadvantage was that enzymes are easily desorbed by changing $\mathrm{pH}$, temperature, ionic strength and substrate or buffer concentration. So the covalent binding of enzyme to the support is prominently used for industrial catalytic applications.

Post synthesis treatment with organic group can maintain strong interaction and the immobilized molecule should be fabricated to the internal pore of the support. Some unexpected advantages are foreseen with suitable organically functionalized mesoporous materials were reported by Lei et al [23]. It has been found that the interactions of the enzyme-support depend strongly on the nature of functional groups attached to the surface. Both amino and glutaraldehyde functionalized supports are most popular for immobilizing enzymes.

Generally co-condensation methods were adopted and it provides homogeneous distribution of functional groups within short reaction time [24]. A tight association between a biocatalyst and the carrier by means of shared pair of electrons and moreover the stress between the support and enzymes can be reduced by joining a spacer group. The spacer molecule provides a greater degree of mobility to the immobilized catalyst. It is stronger and stable than ionic bond and reduces leaching of enzyme into surrounding solution. This means immobilization increases the stability of the biomole- cules and thereby increasing catalytical behavior.

Mesoporous silica materials contain abundant silanol groups for functionalization and enzyme binding. To improve enzyme binding and prevent leaching we focused our interest to functionalized mesoporous silica material. In this present work amino and glutaraldehyde functionalized mesoporous silica materials were used for GA immobilization. Silica materials having large pore diameter was suitable to inco-operate the enzyme molecule inside the pore to protect them from leaching and heat. Immobilized GA showed high thermal stability, storage and reusability. So it can reduce the cost of enzyme and efficiently used for industrial applications.

\section{Materials and Methods}

Tetra ethyl orthosilicate (98\%, Sigma Aldrich), Pluronic P123 (Sigma Aldrich), n-decane (98\%, S.d. Fine Chemicals), 3-aminopropyl triethoxysilane (3APTES 98\%, Sigma Aldrich), glutaraldehyde (25\% solution, Sigma Aldrich) and Aspergillus niger glucoamylase (Sigma - Aldrich).

\subsection{Synthesis of Silane and Glutaraldehyde modified mesoporous silica (MSS and MSG)}

The MS were synthesized as per method described by Zaho et al. [25] in aqueous hydrochloric acid using triblock co-polymer surfactant pluronic P123 [poly(ethylene oxide)-block-poly(propylene oxide)-block-poly(ethylene oxide), EO20-PO70-EO20, Mav $=5800]$ with $n$-decane as the organic swelling agent. Briefly, P123 (2.0 g, $0.3 \mathrm{mmol})$ is dissolved in $\mathrm{HCl} 2 \mathrm{M}$ containing $\mathrm{n}$-decane at $50{ }^{\circ} \mathrm{C}$. The resultant solution was rapidly mixed with silica precursor under vigorous stirring to form a reactive gel having composition $1 \mathrm{~g}$ of $\mathrm{P} 123,1 \mathrm{~g}$ of $\mathrm{n}$ Decane, $2 \mathrm{~g}$ of TEOS, and $8 \mathrm{~g}$ of HCl. $\mathrm{pH}$ of the resulting mixture was maintained below $2(\mathrm{pH}<2)$. The synthesis was carried out under hydrothermal conditions by treating the precursor gel at $100{ }^{\circ} \mathrm{C}$ for $48 \mathrm{~h}$ in Teflon lined autoclave. The solid samples were separated by filtration, washed thoroughly with deionized water, dried at ambient temperature and calcined at $500{ }^{\circ} \mathrm{C}$ for $8 \mathrm{~h}$ and designated as MS.

The synthesized MS was amino functionalized by condensing $0.5 \mathrm{~g}$ solid with $1-5 \mathrm{mmol} 3$-APTES solution in $100 \mathrm{~mL}$ acetone at $40^{\circ} \mathrm{C}$ for $8 \mathrm{~h}$ with constant stirring under an inert nitrogen atmosphere. Products were separated by filtration washed with soxhlet extraction, dried at ambient temperature and designated as MSS. Following this amino functionalized silica sample was treated 
with 1-5 mmol solution of glutaraldehyde in distilled water for $8 \mathrm{~h}$ at $40{ }^{\circ} \mathrm{C}$. The products were cooled, filtered and washed with distilled water till excess gluteraldehyde was removed which was tested by Tollens reagent then dried at $60{ }^{\circ} \mathrm{C}$ for 6 $\mathrm{h}$ and designated as MSG.

\subsection{Immobilization of Glucoamylase on MSS and MSG}

$1 \mathrm{~g}$ support was mixed with $20 \mathrm{ml}$ of $100 \mathrm{mM}$ buffer [pH 3-5.5 phthalate and 6-8 phosphate] solution and $0.1 \mathrm{mg} / \mathrm{mL}$ glucoamylase solution and shaken in a Remi CIS-24BL incubator shaker at 30 ${ }^{\circ} \mathrm{C}$ for $1 \mathrm{~h}$ and shaking speed is maintained at 200 $\mathrm{rpm}$. The immobilized enzyme was centrifuged in a Remi PR-24 compufuge, at $14500 \mathrm{rpm}$ and $40{ }^{\circ} \mathrm{C}$ for $30 \mathrm{~min}$, after that it was separated by filtration and washed with the same buffer solution until no protein is detected. The amount of enzyme protein was estimated using the spectroscopic method of Lowery using Folin - Cioclataues's phenol reagent [26] and absorption is measured at $640 \mathrm{~nm}$. Enzyme immobilized on MSS and MSG was designated as MSSE, MSGE, respectively.

\subsection{Characterization of meso silica, function- alized and immobilized materials}

The X-ray diffraction measurements of the samples were taken on a Panalytical Xpert PRO MPD model with $\mathrm{Ni}$ filtered $\mathrm{Cu} \mathrm{Ka}$ radiation $(\lambda=1.5406 \AA)$ within the $2 \theta$ range $0.1-5^{\circ}$ at a speed of $0.25 \%$ min at room temperature. Nitrogen physisorption measurements were done in a Micromeritics Tri-Star 3000 surface area and porosity analyzer (degassing conditions - $\mathrm{N}_{2}$ atmosphere, $200{ }^{\circ} \mathrm{C}$ for MS, and room temperature for other
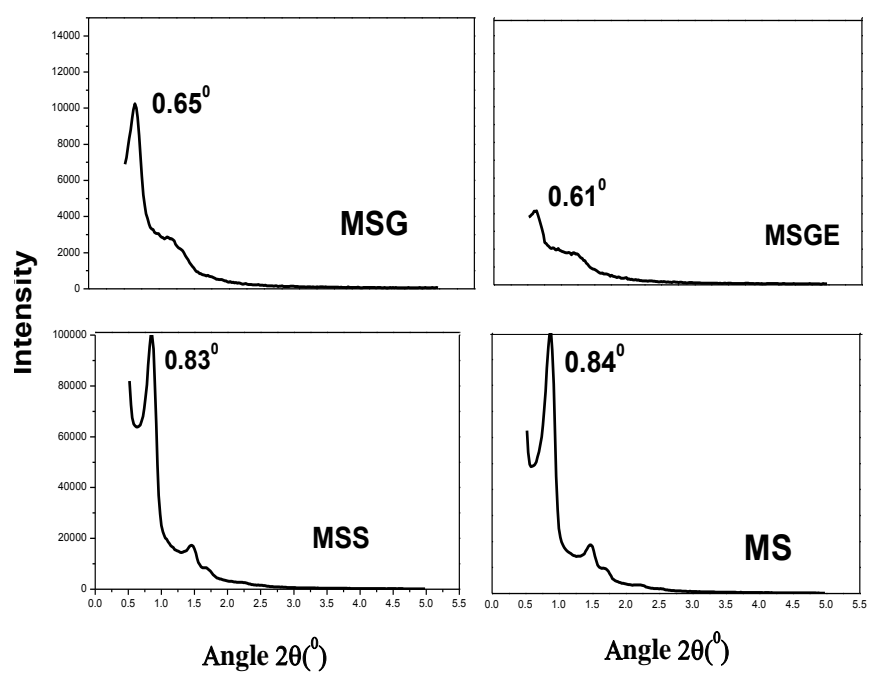

Fig. 1. Small angle XRD pattern of samples samples, time $12 \mathrm{~h})$. Si environment of the samples were analyzed by ${ }^{29} \mathrm{Si}$ MAS solid state NMR. These experiments were carried out over a Bruker DSX300 spectrometer at a resonance frequency of 78.1 $\mathrm{MHz}$ (sample spinning frequency was $8 \mathrm{kHz}, 10 \mathrm{~ms}$ pulse length, pulse delay $2 \mathrm{~s}$ and number of scans 1024) and tetra methyl silane is used as internal standard.

\subsection{Catalytic activity measurements}

Activity of enzyme was measured in batch reactor. The reaction was carried out with $1 \mathrm{~mL}$ of free enzyme solution (0.05 g immobilized enzyme) and 3 $\%(\mathrm{w} / \mathrm{v})$ starch solution at $\mathrm{pH}=5.5$. After the reaction time, the reaction mixture is centrifuged and 1 $\mathrm{mL}$ of filtrate was analyzed colorimetrically. Colour was developed using iodine solution and absorbance was recorded at $600 \mathrm{~nm}$. The results obtained compared with absorbance of standard starch solution.

\section{Results and discussion}

\subsection{Small Angle XRD}

XRD analysis indicates mesophase formation and intensity of $d(100)$ reflection is very high at $2 \Theta \approx 0.8$. The diffraction due to (100), (110), (200) planes are characteristic for meso compounds and with p6mm symmetry. Fig. 1 suggests that the prepared material has hexagonal ordered pore structure. MS shows an intense peak at $2 \theta=0.84^{\circ}$ and corresponding d-space value is $105.090 \AA$. After functionalization and immobilization, $2 \theta$ value shifted towards lower values and one diffraction signal vanished in the case of enzyme loaded MSS and MSG indicates that immobilization disturbs

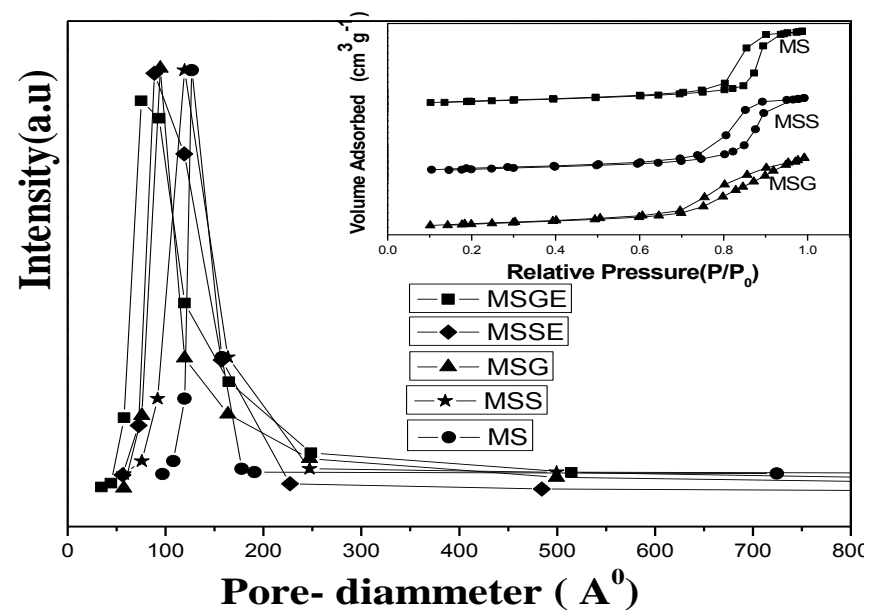

Fig. 2. Nitrogen adsorption - desorption isotherms and Pore size distribution of samples 
Table 1. XRD results of samples

\begin{tabular}{cccc}
\hline Catalyst & $\mathbf{2 \Theta}$ & $\mathbf{d}(\mathbf{1 0 0}) \AA$ & $\mathbf{a ( 1 0 0 ) \AA}$ \\
\hline MS & 0.84 & 105.09 & 121.35 \\
MSS & 0.83 & 106.40 & 122.86 \\
MSG & 0.65 & 135.86 & 156.88 \\
MSSE & 0.67 & 131.67 & 152.03 \\
MSGE & 0.61 & 144.79 & 167.19 \\
\hline
\end{tabular}

Table 2. Surface area, pore diameter and pore volume of samples

\begin{tabular}{cccc}
\hline Catalyst & $\begin{array}{c}\text { Surface } \\
\text { Area } \\
\left(\mathbf{m}^{2} / \mathbf{g}\right)\end{array}$ & $\begin{array}{c}\text { Pore } \\
\text { Diameter } \\
(\AA ̊ \AA)\end{array}$ & $\begin{array}{c}\text { Pore Vol- } \\
\text { ume } \\
\left(\mathbf{c m}^{3} / \mathbf{g}\right)\end{array}$ \\
\hline MS & 479 & 120 & 1.6923 \\
MSS & 334 & 106 & 1.0722 \\
MSG & 303 & 94 & 0.9626 \\
MSSE & 129 & 79 & 0.9923 \\
MSGE & 125 & 77 & 0.4060 \\
\hline
\end{tabular}
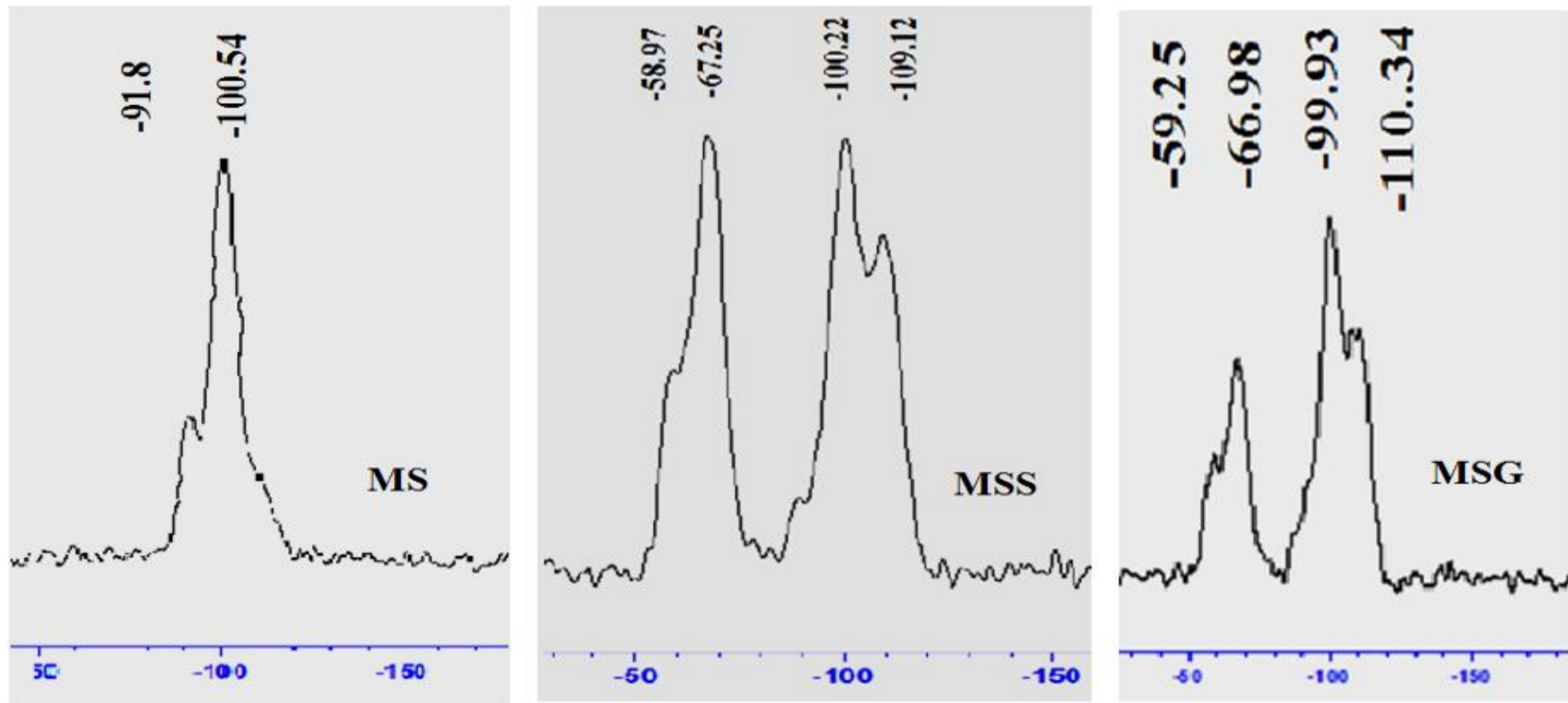

Fig. 3. ${ }^{29}$ Si MAS spectrum of samples

the ordered structure of mesoporous silica. The $d$ (100) values and the unit cell parameters calculated were shown in Table 1. It describes that the angle shifted towards lower value and $d$-spacing value increases. The result indicates that functionalization and immobilization take place in the pore and it can cause the pore blockage.

\subsection{Nitrogen adsorption-desorption studies}

Figure 2 shows that all the samples exhibit type IV adsorption isotherm with $\mathrm{H} 1$ hysteresis loop, characteristic of typical 1D hexagonal cylindrical mesoporous material. The surface area decreases from 334 to $125 \mathrm{~m}^{2} / \mathrm{g}$ and pore volume 1.0722 to $0.0406 \mathrm{~cm}^{3} / \mathrm{g}$, demonstrates that silane and enzymes are directly linked to the hydroxyl group which can cause pore blockage of meso channels of the silica material. Table 2 shows the decrease in pore diameter from 120 to $106 \AA$ after functionalization with 3-APTES and reduces to $79 \AA$ after enzyme loading. Functionalization with glutaraldehyde also shows similar trend.

\section{3. ${ }^{29} \mathrm{Si}$ MAS spectral studies}

The ${ }^{29}$ Si MAS spectrum of the MS exhibits two resonance peaks at $-100.54 \mathrm{ppm}$ for $\mathrm{Q}^{3}$ environment with a shoulder at $-91.38 \mathrm{ppm}$ responsible for $\mathrm{Q}^{2}$ environment. It is observed (Fig. 3) that $\mathrm{Q}^{4}$ peak is absent which indicates a lower degree of condensation of silicate species and intense $\mathrm{Q}^{3}$ peak is due to mesophase prepared under acidic conditions. Two additional peaks were observed $\mathrm{T}^{2}$ at -59.97 

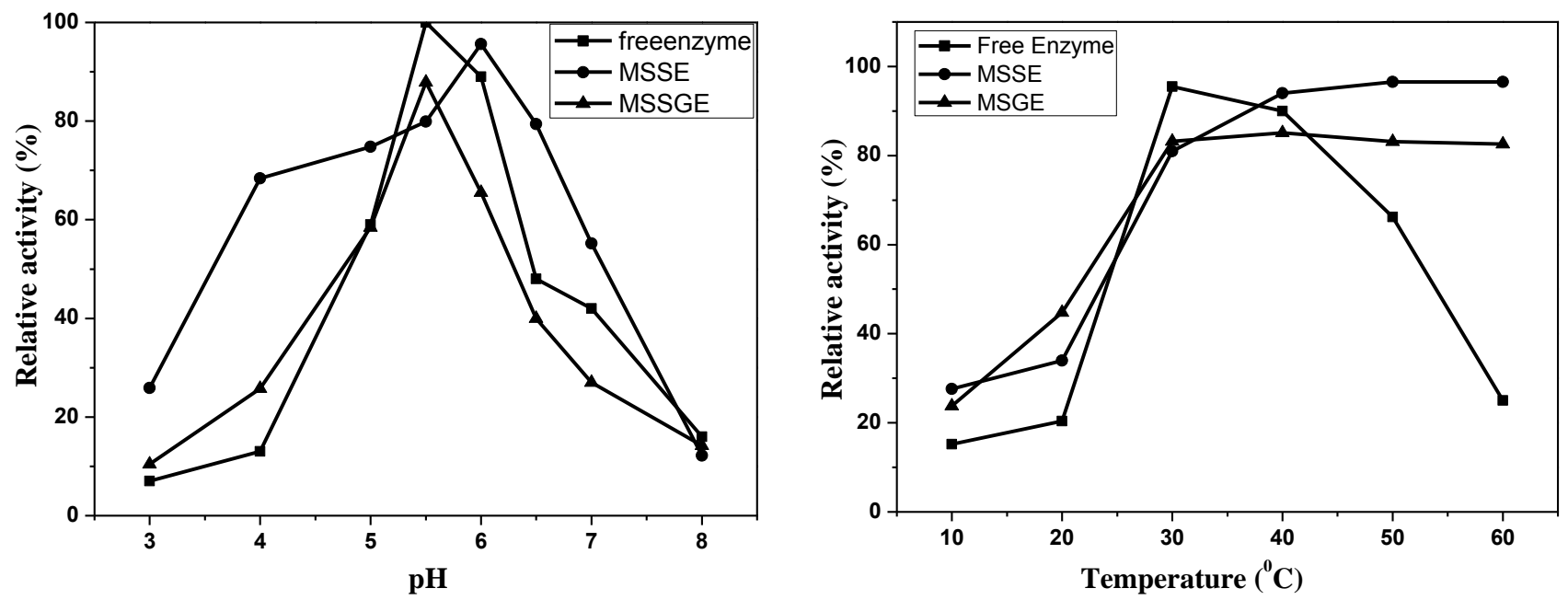

Fig. 4. Effect of immobilization $\mathrm{pH}$ and temperature on activity of MSSE and MSGE

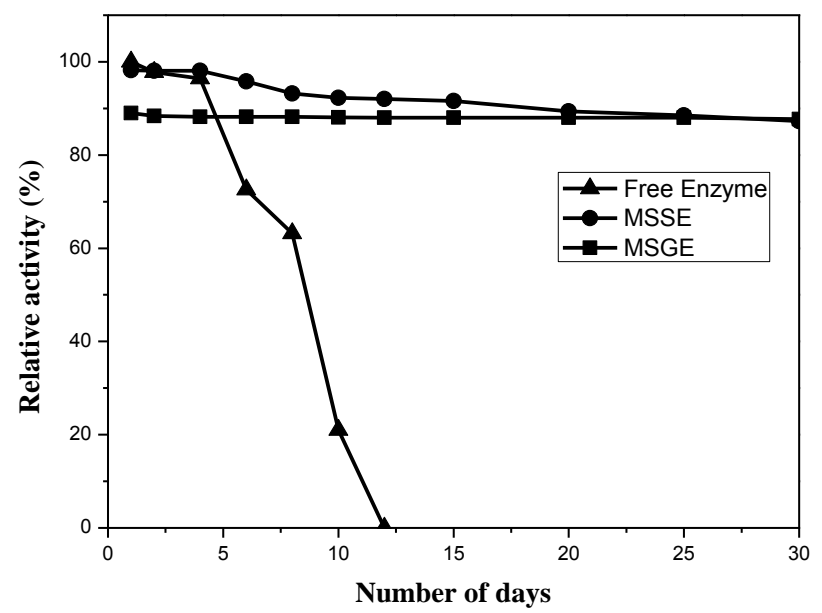

Figure 5. Activity of immobilized glucoamylase stored for 30 days

pm and $\mathrm{T}^{3}$ at $-67.25 \mathrm{ppm}$ due to silane organic moiety [27] which confirms APTES functionalized on the MS silica. The shift in resonance of $\mathrm{T}^{2}$ from 59.97 to $-59.25 \mathrm{ppm}$ and peak due to $\mathrm{T}^{3}$ from -67.25 to 66.98 was observed after covalent binding with glutaraldehyde.

\subsection{Activity studies}

\subsubsection{Effect of $\mathrm{pH}$}

The influence of $\mathrm{pH}$ on activity of free and immobilized enzyme was studied at different $\mathrm{pH}$ range $3-8$ by keeping temperature at $30{ }^{\circ} \mathrm{C}$ and other conditions constant. Free enzyme showed optimum $\mathrm{pH}$ of 5.5 whereas in the case of MSSE, $\mathrm{pH}$ shifts towards 6. But for MSGE the optimum pH remains same as that of free enzyme at $30^{\circ} \mathrm{C}$ were shown in Fig. 4. This is because of poly anionic nature of amino functionalized silica. If the enzyme is

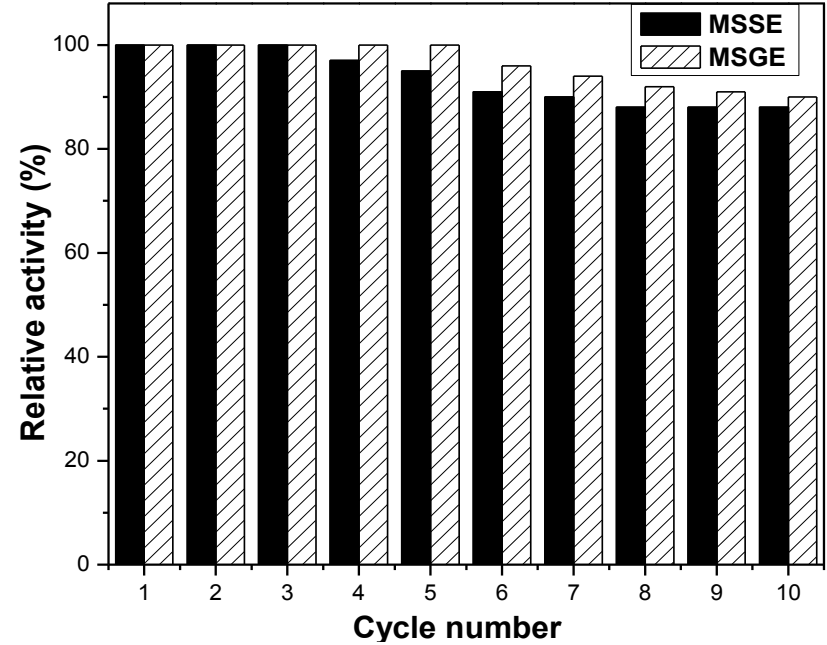

Figure 6. Reusability of MSSE and MSGE

covalently coupled to a polyanionic carrier, the optimum $\mathrm{pH}$ shifts in the alkaline direction.

\subsubsection{Effect of temperature}

Enzyme requires relatively low temperature for reaction. Optimum temperature measurements of immobilized enzymes are conducted in optimum $\mathrm{pH}$ for $1 \mathrm{~h}$ at different temperature range $10-60^{\circ} \mathrm{C}$ keeping all other conditions constant. Immobilized enzyme significantly retained about $85 \%$ activities even after $60{ }^{\circ} \mathrm{C}$ (Fig. 4). The free glucoamylase shows a sharp drop in activity with time indicating a high rate of inactivation. After 30 min preincubation, free enzyme loses almost all activity while covalently bound enzyme hold over $80 \%$ of its initial activity. This result indicates the enhanced thermal stability of glucoamylase after immobilization. Immobilized enzymes resist towards temperature 
inactivation, so covalently bound enzyme shows $85 \%$ activity at $60^{\circ} \mathrm{C}$.

\subsubsection{Storage Stability}

The storage stability measurements were conducted in optimum $\mathrm{pH}$ buffer solution at $4{ }^{\circ} \mathrm{C}$ for a period of 30 days in one batch and activity measured in 2-3 day interval, keeping all other conditions constant. Fig. 5 showed that free enzyme lost its complete activity even after 12 days. Silane bound enzyme in mesoporous silica retains about $87 \%$ activity after 30 days but for gluteraldehyde bound enzyme the activity is almost same after 30 days enzyme because it protects enzyme more effectively against denaturation. This decrease in activity was due to the time-dependent natural loss in enzyme activity. Immobilization improved storage stability of short lived enzyme. Reusability and storage stability are the main goal of enzyme immobilization in industrial applications.

\subsubsection{Reusability of Immobilized Enzyme}

Fig. 6 shows the relative activities of immobilized glucoamylase and the studies were performed at optimal conditions in a batch reactor. After 10 reuses, the residual activity of glutaraldehyde bound enzyme retained $90 \%$ activity. MSGE retains $100 \%$ activity after five runs and MSSE maintains around $88 \%$ activity .This results confirmed the better stability of immobilized enzyme during repeated use than other reported supports. $\mathrm{Cu}$ ion chelated with FeSBA-15-PGMA@imidazole shows similar results in reusability studies was reported by Zaho et al. [28]. It has been reported that salt and base forms of poly (o-toluidine) retained $80-85 \%$ of initial activity after 8 cycles [29].

Mesoporous silica materials have large pore diameter than glucoamylase molecule. It can easily attach enzyme molecule directly into the pore. Decrease in pore volume and pore diameter were confirmed by nitrogen adsorption desorption studies. After enzyme immobilization reduction in sharpness of hysteresis loop indicates that enzymes are immobilized inside the pore. The silica molecule has high thermal stability so it can protect the enzyme molecule from denaturation. Stability and life span of enzyme can be improved by immobilization

\section{Conclusions}

Highly ordered hexagonal mesoporous silica has been synthesized hydrothermally through an auxiliary chemical decane under acidic conditions using TEOS and P123. Low angle XRD shows the formation of meso phase. Pore diameter and surface area were analyzed, decrease in pore volume and surface area indicates that silane, glutaraldehyde are directly linked to the pores. Enzyme immobilized amino functionalized mesoporous silica showed more activity than enzyme bound gluteraldehyde. Functionalization with glutaraldehyde causes decrease in activity due to the presence of glutaraldehyde near the active site. An increase in operational temperature is observed for immobilized enzyme which conveys the effective protection against thermal denaturation of enzyme. The covalently bound glucoamylase shows enhanced storage stability and therefore increases its industrial applications. Results demonstrate that both immobilized enzymes exhibits enhanced storage stability and reusability than free enzyme.

\section{Abbreviations \\ MS - mesoporous silica \\ MSS- Silane modified mesoporous silica \\ MSG- Gluteraldehyde modified mesoporous silica \\ MSSE- Enzyme immobilized on MSS \\ MSGE- Enzyme immobilized on MSG \\ GA - Glucoamylase}

\section{References}

[1] Sanjay, G., Sugunan, S. (2005). Glucoamylase immobilized on montmorillonite: Synthesis, characterization and starch hydrolysis activity in a fixed bed reactor. Catalysis Communications, 6: 525530

[2] Shankar, V., Nehete, P.N., Kothari, R.M. (1993). Immobilization of amyloglucosidase. Indian Journal of Biochemistry and Biophysics, 30: 62-70

[3] Balasubramaniam, K., Arasartnam, V. (1989). Kinetic studies on soluble and immobilized alpha amylase and glucoamylase. Journal of National Science Council Srilanka, 17: 91-97.

[4] Gaoxiang, L., Jiayu, H., Xiufen, K. (1982). Glucoamylase covalently coupled to porous glass. Applied Biochemistry and Biotechnology, 7: 325-341.

[5] Huo, Y., Huang, J., Yuan, Z., Jiaxianhuang. (2004). Immobilization of glucoamylase onto novel porous polymer supports of vinylene carbonate and 2hydroxyethyl methacrylate. Applied Biochemistry and Biotechnology.119: 121-131

[6] Jayraju, K., Ayyanna, C., Padmasree, D. (1991). Indian Journal of Chemical Engineering, 33: 47-50

[7] Chen ,Guo., Ma ,Yunhui., Su ,Pengfei., Fang , Baishan. (2012) Direct binding glucoamylase onto carboxyl-functioned magnetic nanoparticles. Biochemical Engineering Journal. 67:120-125

[8] Zhao, G.H., Li, , Y.F, Wang, J.Z., Zhu, H. (2011). Reversible immobilization of glucoamylase onto magnetic chitosan nanocarriers. Applied Microbiology and Biotechnology, 91: 591-601. 
[9] Wu, S.C., Lia, Y.K. (2008). Application of bacterial cellulose pellets in enzyme immobilization. Journal of Molecular Catalysis B: Enzymatic, 54: 103108

[10] Tardioli, P.W., Vieira, M.F., Vieira, A., Zanin, M., Betancor, G.M., Mateo, L., Fernández-Lorente, C., Guisán, G. (2011) Immobilization-stabilization of glucoamylase: Chemical modification of the enzyme surface followed by covalent attachment on highly activated glyoxyl-agarose supports. Journal of Molecular Process Biochemistry. 46: 409412

[11] Galina, A., Kovalenko, L., Perminova, V. (2008). Immobilization of glucoamylase by adsorption on carbon supports and its application for heterogeneous hydrolysis of dextrin. Carbohydrate Research, 343: 1202-1211

[12] Cecilia, C., Batista, V., Ruales, F. (2011). Improved glucoamylase immobilization onto calcined chicken bone particles. Journal of Food Bioprocess Technology, 4: 1186-1196

[13] Anna, W., Jersey, L., Teresa, B. (1990). Comparison of upper gastrointestinal toxicity of rofecoxib and naproxen in patients with rheumatoid arthritis. Journal of Chemical Technology and Biotechnology, 48: 287-300

[14] Yu, K., He, J., Guo, X. (2007). Influence of Pore Diameters on the Immobilization of Lipase in SBA-15. Industrial \& Engineering Chemistry Research, 46: 4474-4479

[15] Hartmann, M., (2005). Ordered Mesoporous Materials for Bioadsorption and Biocatalysis. Chemistry of Materials, 17: 4577-4593

[16] Pandya, P.H., Jasra, R.V., Newalkar, B.L., Bhatt, P.N. (2005). Studies on the activity and stability of immobilized a-amylase in ordered mesoporous silicas. Microporous Mesoporous Materials, 77: 67-77.

[17] Sing, K.S.W., Gregg, S.J. (1982). Adsorption Surface Area and Porosity. 2-nd ed. 80: 857-865

[18] Zaho, D.Y., Feng, J.L., Huo, Q.S., Melosh, N., Fredrickson, G.H., Chmelka, B.F., Stucky, G.D. (1998). Nonionic triblock and star diblock copolymer and oligomeric surfactant syntheses of highly ordered, hydrothermally stable, mesoporous silica structures. Science 279: 548-552

[19] Yu, C.Z, Fan, J., Tian, B.Z., Zaho, D.Y., Stucky, G.D. (2002). High-yield synthesis of periodic mesoporous silica rods and their replication to mesoporous carbon rods. Advanced Materials, 11: 17421745
[20] Yang, H.F., Shi, Q.H., Tian, B.Z., Xie, S.H., Zhang, F.Q., Yan, Y., Tu, B., Zaho, D.Y. (2003). A fast way for preparing crack-free mesostructured silica monolith. Chemistry of Materials. 15: $536-541$

[21] Zaho, D.Y., Yang, P.D., Chmelka, B.F., Stucky, G.D. ( 1999). Multiphase assembly of mesoporous-macroporous membranes. Chemistry of Materials, 11: 1174-1178

[22] Namba, S., Mochizuki, A. (1998). Effect of auxiliary chemicals on preparation of silica MCM- 41 . Research on Chemical Intermediates, 24: 561570

[23] Lei, C.H., Shin, Y.S., Liu, J., Ackerman, E.J. (2002). Entrapping enzyme in a functionalized nanoporous support. Journal of American Chemical Society, 124: 11242-11243

[24] Ajayan, V., Kazi, Z.H., Katsuhiko, A. (2005). Recent advances in functionalization of mesoporous silica. Journal of Nanoscience and Nanotechnolog, 5: 347-371

[25] Zaho, D., Huo, Q., Stucky, G.D. (1998). Nonionic triblock and star diblock copolymer and oligomeric surfactant syntheses of highly ordered, hydrothermally stable, mesoporoussilica structures. Journal of American Chemical Society, 120: 6024-6036

[26] Lowry, O.H., Rosebrough, N.J., Farr, A.L., Randall, R.J. (1951). Protein measurement with the Folin phenol reagent. Journal of Biological Chemistry, 193: 265-275

[27] Hossein, N., Xiaojian, G.J. (2007). Characterization of sol-gel immobilized lipases. Sol-Gel Science and Technology, 41: 31-41

[28] Zhao, G., Wang, J., Li, Y., Huang, H., Chen, X. (2012). Reversible immobilization of glucoamylase onto metal-ligand functionalized magnetic FeSBA-15. Biochemical Engineering Journal, 68: $159-166$

[29] Ashly, P.C., Mohanan, P.V. (2010). Preparation and characterization of Rhizopus amyloglucosidase immobilized on poly(o-toluidine). Process Biochemistry, 45: 1422-1426 